\title{
SEBARAN INFEKSI TAURA SYNDROME, INFECTIOUS MYONECROSIS, DAN Penaeus vannamei NERVOUS VIRUS (TSV, IMNV, DAN PvNV) PADA BUDIDAYA UDANG Litopenaeus vannamei DI JAWA BARAT, JAWA TIMUR, DAN BALI
}

\author{
Isti Koesharyani" "\#, Lila Gardenia"', dan Tatik Mufidah") \\ ") Pusat Penelitian dan Pengembangan Perikanan Budidaya \\ ") Balai Penelitian dan Pengembangan Budidaya Air Tawar
}

(Naskah diterima: 27 Agustus 2014; Revisi final: 14 Agustus 2015, Disetujui publikasi: 2 September 2015)

\begin{abstract}
ABSTRAK
Pada budidaya udang introduksi Litopenaeus vannamei, virus merupakan penyakit yang memberi dampak cukup merugikan dan menimbulkan kematian massal budidaya udang vaname. Tujuan penelitian ini adalah untuk mengetahui sebaran adanya infeksi virus di beberapa daerah budidaya udang $L$. vannamei, di Jawa Timur (Bangil, Banyuwangi, Situbondo), Bali, dan Jawa Barat (Karawang dan Mauk-Tangerang). Jenis virus yang dianalisis adalah Taura Syndrome (TSV), Infectious Myonecrosis (IMNV), dan Penaeus vannamei Nervous Virus $(P v N V)$ dan merupakan golongan RNA virus. Sebanyak 5-10 ekor sampel diambil dari setiap daerah secara individu berupa jaringan insang, pleopod, dan daging, disimpan dalam RNAlater. Selanjutnya sampelsampel tersebut dianalisis di Laboratorium Kesehatan Ikan, Pusat Penelitian dan Pengembangan Perikanan Budidaya, Jakarta. Metode analisis menggunakan Reverse-Transcription Polymerase Chain Reaction (RTPCR) dengan spesifik primer: TSV (230 bp), IMNV-1 (600 bp), PvNV-1 (339 bp). Hasil analisis RT-PCR, menunjukkan bahwa dari 56 sampel, ternyata infeksi TSV diperoleh di lokasi budidaya udang di Bangil, Banyuwangi, dan Bali. Sementara, kasus infeksi IMNV terdapat di Banyuwangi dan Bali, sedangkan infeksi $P v$ NV yang merupakan penyakit baru tidak diperoleh dari semua sampel yang ada. Beberapa sampel uji menunjukkan multi infeksi secara alami antara TSV-IMNV yang berasal dari budidaya di Banyuwangi. Mengingat, kasus infeksi PvNV belum pernah ada di Indonesia, maka perlu aturan tata cara impor atau pengawasan tentang udang vaname agar tidak terjadi introduksi penyakit virus baru ke Indonesia.
\end{abstract}

KATA KUNCI: ～Litopenaeus vannamei, TSV, IMNV, PvNV, RT-PCR

ABSTRACT: Distribution of infection taurasyndrome, infectious myonecrosis and Penaeus vannamei nervous virus (TSV, IMNV, and PvNV) in Litopenaeus vannamei cultured in West Java, East Java, and Bali. By: Isti Koesharyani, Lila Gardenia, and Tatik Mufidah

Virus infection frequently caused mass mortality in vannamei culture. The purpose of this study was to determine the distribution of virus infection in cultured from Bangil, Banyuwangi, Situbondo, Bali, Karawang, and Mauk-Tangerang. Individually 5 to 10 gill tissue, pleopod or muscle of shrimps were taken from each region then stored in preservative solution RNAlater. Samples will than be analyzed at Fish Health Research Laboratory, Jakarta. Tisssue samples were examined by Reverse-Transcription Polymerase Chain Reaction (RT-PCR) using specific primers: TSV (230 bp), IMNV-1 (600 bp), and PvNV-1 (339 bp). The results of RT-PCR analysis revealed that from a total of 56 samples, TSV infected in Bangil, Banyuwangi, and Bali farm, while IMNV infected in Banyuwangi and Bali farm, and PvNV is relatively new disease, did not detected in any samples. In Banyuwangi farm, shrimp was naturally infected by both TSV and IMNV. In other to avoid infection of PvNV as new virus to Indonesia, the regulation of imported $L$. vannamei have to be strengthen.

KEYWORDS: Litopenaeus vannamei, TSV, IMNV, PvNV, RT-PCR

\# Korespondensi: Pusat Penelitian dan Pengembangan Perikanan Budidaya. Jl. Ragunan No. 20, Pasar Minggu, Jakarta Selatan 12540, Indonesia. Tel.: + (021) 7805052

E-mail: istisugama@yahoo.com 


\section{PENDAHULUAN}

Budidaya udang di Indonesia merupakan akuabisnis yang sudah dimulai sejak lama dan merupakan komoditas strategis yang dapat meningkatkan devisa negara. Perkembangan budidaya udang banyak dihadapkan pada permasalahan yaitu adanya penyakit yang disebabkan oleh virus, seperti kasus white spot syndrome virus (WSSV) yang menginfeksi Penaeus monodon yang mengakibatkan kerugian yang tidak sedikit pada tahun 1990-an. Akibat kejadian tersebut, maka pada tahun 2001 pemerintah memberi ijin impor udang jenis Litopenaeus vannamei yang berasal dari Amerika Latin. Jenis udang ini mempunyai keunggulan komperatif. Tetapi sejalan dengan perkembangan budidaya udang tersebut, maka timbul masalah di antaranya infeksi penyakit virus yang masuk bersamaan dengan udang introduksi tersebut. Kasus penyakit yang terjadi umumnya disebabkan oleh patogen terutama jenis RNA virus dan berbahaya terhadap L. vannamei di mana golongan RNA virus sangat mudah mutasi, sehingga dapat berubah menjadi lebih ganas. Kasus mutasi ini terjadi pada strain TSV yang ditemukan di Colombia pada tahun 2010 dengan sifat yang lebih ganas dibandingkan dengan TSV pada tahun 1994-1998. (Aranguren et al., 2013).

TSV adalah salah satu penyakit virus yang cukup berbahaya, dapat menyebabkan kematian 40\%-95\% pada populasi udang stadia post larvae dan juvenile. Virus ini pertama kali diketahui pada tahun 1992 di Ecuador (Poulos et al., 1999). TSV digolongkan dalam small dan non-enveloped virus, berbentuk icosahedral, mengandung single-stranded positive-sense RNA dengan jumlah nukleotid 10,205 (Bonami et al., 1997; Mari et al., 2002 dalam Kiatpathomchai et al., 2007; OIE, 2015) dan diklasifikasikan ke dalam Famili Dicistroviridae dengan ukuran virion 32 nm (Mayo, 2002 dalam Kiatpathomchai et al., 2007; OIE, 2015). Hasil pemantauan yang dilakukan pada tahun 2003, menunjukkan bahwa TSV sudah menginfeksi budidaya udang P. vannamei di Jawa Timur dan tetap berkembang hingga saat ini.

Jenis infectious myonecrosis virus (IMNV) juga menginfeksi udang L. vannamei. IMNV ditemukan pertama kali di Brazil pada tahun 2004, sedangkan di Indonesia infeksi IMNV pertama kali terjadi di Situbondo Jawa Timur pada tahun 2006 (Senapin et al., 2007). Akibat infeksi virus tersebut menimbulkan kerugian yang besar karena terjadi kematian massal pada budidaya udang L. vannamei. Di Asia, IMNV ini ternyata hanya ditemukan di Indonesia (Senapin et al., 2011). Hasil sekuensing whole genome sampel IMNV dari Indonesia mempunyai kesamaan 99\% dengan IMNV yang berasal dari Brazil. Hal ini sangat dimungkinkan bahwa IMNV berasal dari induk udang Brazil yang telah terinfeksi oleh IMNV dan digunakan untuk kegiatan budidaya dan produksi larva di Indonesia (Senapin et al., 2007).

Informasi penyakit lain yang termasuk dalam jenis RNA-virus yang dilaporkan oleh (Tang et al., 2007) adalah jenis penyakit yang disebabkan oleh Nodavirus dan mengakibatkan musclenecrosis. Penyakit tersebut untuk sementara disebut sebagai Penaeus vannamei nodavirus (PvNV). PvNV pertama diketahui di Belize pada tahun 2004 dan menyebabkan kematian lebih dari 50\% pada budidaya udang yang terinfeksi. Gejala klinis udang yang terinfeksi adalah warna ekor yang buram-memutih di mana gejalanya hampir sama seperti pada kasus IMNV.

Virus-virus tersebut dapat dideteksi dengan beberapa metode, seperti metode molekuler (reverse transcription-polymerase chain reaction(RT-PCR), nested RT-PCR, Real Time RT-PCR, in-situ hybridisation (ISH), dan Reverse transcription loop-mediated isothermal amplification (RT-LAMP) yang dikombinasikan dengan colorimetric gold nanoparticle (AuNP) (Tang et al., 2005; Senapin et al., 2007; Andrade et al., 2007; Suebsing et al., 2013).

Upaya antisipasi kerugian yang disebabkan oleh serangan penyakit yang disebabkan oleh RNA virus (TSV, IMNV, dan $P v \mathrm{NV}$ ) dalam budidaya udang, maka perlu mengetahui status kesehatan udang secara berkala terutama pada udang $L$. vannamei yaitu dengan melakukan monitoring sebaran infeksi terutama virus yang belum ditemukan di Indonesia seperti $P v N V$, sehingga akibat yang ditimbulkan dapat dihindari dan mencegah agar tidak masuk ke Indonesia seperti pada kasus infeksi IMNV.

\section{BAHAN DAN METODE}

\section{Penyiapan Sampel Udang L. vannamei}

Sampel udang L. vannamei dengan berbagai ukuran dikoleksi dari beberapa lokasi budidaya udang yaitu: Bangil, Banyuwangi, Situbondo (Jawa Timur), Bali, serta Karawang dan Mauk-Tangerang (Jawa Barat). Organ yang diambil adalah pleopod, insang dan otot/ daging yang disimpan dalam larutan pengawet RNAlater. Ribonucleic acid (RNA) sampel kemudian diektraksi menggunakan RNA extraction-Kit dan diamplifikasi menggunakan primer spesifik untuk TSV, IMNV, dan PvNV.

\section{Ektraksi Ribonucleic Acid (RNA)}

RNA diekstraksi menggunakan TRIzol, dilakukan sesuai petunjuk yang ada. Sebanyak $25-50 \mathrm{mg}$ sampel pleopod, insang, dan daging masing-masing dimasukkan dalam tabung mikro $(1,5 \mathrm{~mL})$ kemudian ditambahkan larutan Trizol untuk menghancurkan 
jaringan, setelah disentrifugasi pada suhu $4^{\circ} \mathrm{C}$ supernatan ditambahkan Chlorform untuk memisahkan RNA dengan yang lain, kemudian RNA diendapkan dengan mensentrifugasi dengan suhu $4^{\circ} \mathrm{C}$ setelah ditambahkan Isopropanol, selanjutnya RNA dibilas dengan Ethanol dan disentrifugasi kembali. RNA selanjutnya dikering-udarakan dan dicairkan dengan 50-100 $\mu \mathrm{L}$ Aquades yang di-treatment dengan 0,05\% Dietyl Pyrocarbonat (DEPC). Selanjutnya RNA diukur konsentrasinya dengan Nanodrop dan kualitas RNA ditunjukkan dengan nilai $>$ dari 1,8 (perbandingan OD 260 dengan $280 \mathrm{~nm}$ ).

\section{Amplifikasi $c$-DNA Virus TSV, IMNV, dan PvNV dengan RT-PCR}

Amplifikasi Reverse Trancriptase-Polymerase Chain Reaction (RT-PCR) untuk RNA virus, dilakukan dengan menggunakan Access Quick Promega 2x Master Mix (Tfl DNA polymerase, dNTPs, magnesium sulfate, dan Reaction Buffer) dan enzim AMV RT, Primers Reverse dan Forward masing-masing $10 \mathrm{pMol}, 2 \mu \mathrm{L}$ RNA Template dan $\mathrm{H}_{2} \mathrm{O}$ sampai dengan total volume $25(\mu \mathrm{L})$. Susunan spesifik primer dan kondisi siklus amplifikasi masing-masing virus dapat dilihat pada Tabel 1 .

Setelah proses membalikan dari RNA ke c-DNA menggunakan reverse enzyme pada suhu $50^{\circ} \mathrm{C}-60^{\circ} \mathrm{C}$ serta $94^{\circ} \mathrm{C}$, selanjutnya c-DNA diamplifikasi dengan suhu annealing yang berbeda untuk masing-masing target virus di mana TSV menggunakan suhu $60^{\circ} \mathrm{C}$, IMNV $50^{\circ} \mathrm{C}$, dan untuk $P v N V 55^{\circ} \mathrm{C}$. Selanjutnya sampel dielektrophoresis pada $1,5 \%$ agarose dalam larutan penyangga atau buffer $1 x$ TAE (Triss Acetate EDTA). Pita yang dihasilkan diukur atau dibandingkan dengan marker DNA Low range (Fermentas). Visualisasi pita target diwarnai dengan 0,05\% Ethidium Bromida selama 15 menit dan didokumentasikan dengan foto.

\section{HASIL DAN BAHASAN}

Hasil yang diperoleh melalui pengumpulan sampel dari sentra budidaya udang di Bali, Bangil, Banyu- wangi, Situbondo, Karawang dan Mauk-Tangerang, diikuti dengan pencatatan data-data yang diperlukan untuk mengetahui kondisi budidayanya.

Semua sampel uji berupa pleopod, insang, serta otot/daging disimpan dalam larutan pengawet RNAlater. Hal ini mengingat, bahwa target yang akan diektraksi berupa RNA dengan sifat mudah rusak dibandingkan dengan DNA, sehingga pengawetan jaringan sangat menentukan hasil analisis. Menurut Novita et al. (2009), RNAlater mampu menjaga kestabilan dan kualitas RNA hingga jangka waktu sekitar satu tahun penyimpanan. Pengukuran kualitas RNA menggunakan Nanodrop dengan hasil rata-rata antara 50 sampai $500 \mathrm{ng} / \mu \mathrm{L}$ dan tingkat kemurnian 81,8 . Selanjutnya RNA tersebut dibuat konsentrasinya menjadi 30-50 ng/ $\mu$ L untuk diamplifikasi RT-PCR.

Amplifikasi menggunakan RT-PCR Access Quick Promega sangat mudah dan aman dikerjakan karena reaksi amplifikasi dilakukan dalam mikrotube tunggal. Reaksi ini dapat membantu mengurangi risiko cross-contamination yang banyak terjadi pada saat penyiapan reaksi. Siklus kondisi amplifikasi IMNV dilakukan optimasi yaitu pada suhu annealing $50^{\circ} \mathrm{C}$. Sedang untuk amplifikasi TSV dan $P v$ NV sesuai dengan literatur yang digunakan (Nunan et al., 1998; Tang et al., 2007). Hasil analisis deteksi RT-PCR untuk masingmasing virus (TSV, IMNV, dan $P v N V$ ) yang berasal dari beberapa lokasi budidaya dapat dilihat pada Tabel 2 .

Dari hasil deteksi sebaran infeksi masing-masing virus, ternyata status infeksi TSV masih diperoleh pada lokasi budidaya di Jawa Timur, yaitu di Bangil (1/7), Banyuwangi (10/10), dan Bali (2/18) positif, sedangkan infeksi TSV tidak ditemukan di Situbondo, Karawang, dan Tangerang. Pada kasus infeksi IMNV dijumpai di dua lokasi Banyuwangi dan Bali (10/10 dan 2/18; positif). Sementara di lokasi budidaya lain seperti di Situbondo, Karawang, dan Tangerang tidak ditemukan kasus infeksi IMNV. Infeksi PvNV belum ditemukan di semua lokasi. Status adanya infeksi IMNV dan $P v N V$

Tabel 1. Sekuen primer, target, suhu annealing, dan referensi

Table 1. Sequence primers, target, annealing temperature, and references

\begin{tabular}{llcc}
\hline $\begin{array}{c}\text { Nama primer } \\
\text { Primers name }\end{array}$ & \multicolumn{1}{c}{$\begin{array}{c}\text { Sekuen primer } \\
\text { Sequence primers }\end{array}$} & $\begin{array}{c}\text { Suhu annealing } \\
\text { Annealing temperature }\left({ }^{\circ} \mathrm{C}\right)\end{array}$ & $\begin{array}{c}\text { Pustaka } \\
\text { Reference }\end{array}$ \\
\hline TSV-230 & $\begin{array}{l}\text { F: 5'-AAg TAg ACA gCC gCg CTT gC -3' } \\
\text { R: 5'-CAA TgA gAg CTT ggT CCT ggA CT -3' }\end{array}$ & 60 & Nunan et al . (1998) \\
\hline IMNV-600 & F: 5'- AAg TAg ACA gCC gCg CTT gC-3' \\
& R: 5'-CAA TgA gAg CTT ggT CCT ggA CTT-3' & 50 & Senapin et al . (2007) \\
\hline Pv NV-339 & F: 5'- CTg TCT CAC Agg CTg gTT CA-3' & Tang et al . (2007) \\
\hline
\end{tabular}


Tabel 2. Hasil analisis TSV, IMNV, dan PvNV dengan RT-PCR dari sampel uji L. vannamei dari beberapa lokasi budidaya udang

Table 2. Result of analysis RT-PCR analyzed for TSV, IMNV, and PvNV from samples L. vannamei from several location shrimp culture

\begin{tabular}{|c|c|c|c|c|c|c|}
\hline \multirow{2}{*}{$\begin{array}{c}\text { Lokasi } \\
\text { Location }\end{array}$} & \multirow{2}{*}{$\begin{array}{c}\text { Jumlah } \\
\text { sampel } \\
\text { Total } \\
\text { sample }\end{array}$} & \multirow{2}{*}{$\begin{array}{l}\text { Jaringan } \\
\text { Organ }\end{array}$} & \multicolumn{3}{|c|}{$\begin{array}{r}\text { Deteksi RT-PCR } \\
\text { Detection RT-PCR }\end{array}$} & \multirow{2}{*}{$\begin{array}{l}\text { Status udang } \text { L. vannamei } \\
\text { Status of shrimp of L. vannamei }\end{array}$} \\
\hline & & & TSV & IMNV & $\operatorname{Pv} \mathrm{NV}$ & \\
\hline Bangil & 7 & $\mathrm{p} / \mathrm{m} / \mathrm{g}$ & $1 / 7$ & $0 / 7$ & $0 / 7$ & 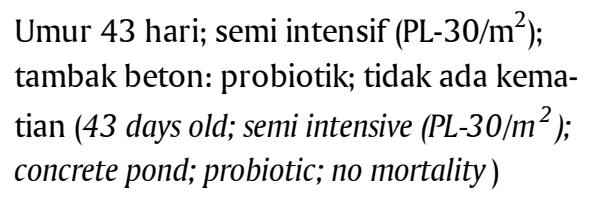 \\
\hline Banyuwangi & 10 & $\mathrm{p} / \mathrm{m} / \mathrm{g}$ & $10 / 10$ & $10 / 10$ & $0 / 10$ & $\begin{array}{l}\text { Umur } 105 \mathrm{hari} \text {; intensif }\left(\mathrm{PL}-125 / \mathrm{m}^{2}\right) \text {; kema- } \\
\text { tian } \pm 4-5 \mathrm{~kg} / \mathrm{hari} \text {; ada gejala TSV pada } \\
\text { umur } 20-40 \text { hari dan gejala Myonecrosis } \\
\text { pada umur }<70 \text { hari }(105 \text { days old; intens- } \\
\text { ive }\left(P L-125 / \mathrm{m}^{2}\right) \text {; mortality } \pm 4-5 \mathrm{~kg} / \text { day; with } \\
\text { TSV symptom on } 20-40 \text { days old and } \\
\text { Myonecrosis symptom on }<70 \text { days old })\end{array}$ \\
\hline Situbondo & 6 & $\mathrm{p} / \mathrm{m} / \mathrm{g}$ & $0 / 6$ & $0 / 6$ & $0 / 6$ & $\begin{array}{l}\text { Umur } 50 \text { hari; intensif }\left(\mathrm{PL}-100 / \mathrm{m}^{2}\right) \text {; umur } \\
30 \text { hari; intensif }\left(\mathrm{PL}-100 / \mathrm{m}^{2}\right) \text {; tambak beton; } \\
\text { tidak ada kematian ( } 50 \text { days old; intensive (PL- } \\
\left.100 / \mathrm{m}^{2}\right) \text {; L. vannamei } 30 \text { days; intensive } \\
\left(100 \mathrm{PL} / \mathrm{m}^{2}\right) \text {; concrete pond; no mortality) }\end{array}$ \\
\hline
\end{tabular}

\begin{tabular}{|c|c|c|c|c|c|c|}
\hline Karawang & 10 & $\mathrm{p} / \mathrm{m}$ & $0 / 10$ & $0 / 10$ & $0 / 10$ & 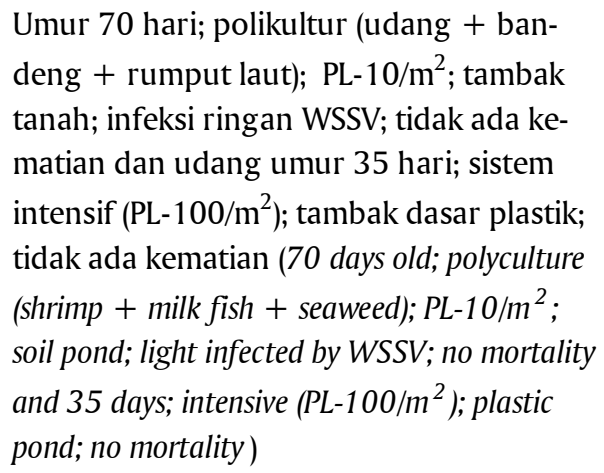 \\
\hline Bali & 18 & $\mathrm{p} / \mathrm{m} / \mathrm{g}$ & $2 / 18$ & $2 / 18$ & $0 / 18$ & $\begin{array}{l}\text { Udang berbagai umur ( } 20 \text { hari- } 6 \text { bulan); } \\
\text { tambak beton (sistem tertutup) (Various ages } \\
20 \text { days- } 6 \text { months; concrete pond (closed } \\
\text { system)) }\end{array}$ \\
\hline Tangerang & 5 & $\mathrm{p} / \mathrm{m}$ & $0 / 5$ & $0 / 5$ & $0 / 5$ & $\begin{array}{l}\text { Udang umur } 30 \text { hari; semi-tradisional; } \\
\left.20.000 \mathrm{PL} / 4.000 \mathrm{~m}^{2}\right) \text {; tambak tanah }(30 \\
\text { days old; semi-tradisional }(20,000 \mathrm{PL} / 4,000 \\
\left.\left.\mathrm{m}^{2}\right) \text {, soil pond }\right)\end{array}$ \\
\hline
\end{tabular}

Total sampel 56

Total samples

Keterangan (Note):

$\mathrm{p}=$ Pleopod; $\mathrm{m}=$ Otot (Muscle); $\mathrm{g}=$ Insang $($ Gill $)$ 
pada udang vaname dilakukan juga oleh (Senapin et al., 2011) pada tahun 2006-2011 dari beberapa lokasi budidaya udang di Asia (Indonesia, Thailand, Cina, Malaysia, Taiwan, Vietnam, dan India). Hasil yang diperoleh ternyata infeksi IMNV hanya ditemukan di Indonesia, sedangkan $P v \mathrm{NV}$ belum ditemukan di Asia. Hasil tersebut sesuai dengan pengamatan yang dilakukan pada penelitian ini. Hasil sebaran virus RNA (TSV, IMNV, dan $P v \mathrm{NV}$ ) pada beberapa lokasi sentra budidaya udang vanamei dapat dilihat pada Gambar 1 .

Kasus menarik yang ditemukan di Banyuwangi, ternyata dari sepuluh sampel uji teridentifikasi adanya multi infeksi (TSV dan IMNV) dalam udang yang sama dan terjadi secara natural. Umumnya kasus udang yang terinfeksi IMNV secara histopatologi menunjukkan adanya interstitial non-suppuratif myotsistis disertai multifokal degenerasi dan nekrosis pada serat otot kadang disertai adanya pembengkakan di antara jaringan otot yang terinfeksi (Mufidah et al., 2009; OIE, 2009). Sedangkan diagnosis TSV secara histopatologi ditandai adanya erosi hingga menginvasi pada bagian kutikel yang terinfeksi. Sedangkan mekanisme penularan pada kasus infeksi virus pada budidaya udang secara umum melalui dua cara yaitu transmisi secara horizontal dan vertikal. Penularan secara horisontal yaitu dengan kanibalisme atau air yang terkontaminasi. Penularan secara vertikal adalah melalui induk ke anakannya. Dari informasi yang didapat, kasus natural multi-infeksi pada saat itu, diawali dengan adanya gejala kematian yang terjadi secara masif dengan rata-rata kematian sebanyak $4-5$ kg/ hari. Mortalitas didahului dengan adanya gejala awal terinfeksi TSV yaitu adanya chromathopore berupa bercak coklat kemerahan pada permukaan badan udang yang dimulai pada saat udang berumur 20-40 hari. Gejala infeksi TSV yang ditemukan di Banyuwangi ini sesuai dengan yang ditemukan oleh Lightner et al. (1995) yaitu adanya melanisasi pada kulit yang disebut dengan penyakit kulit 'shell diseases' (Gambar 2A) keadaan ini terus berlanjut hingga muncul adanya gejala IMNV pada lokasi yang sama dan terjadi pada umur $<$ dari 70 hari.

Gejala IMNV pada sampel udang yang diperoleh di Banyuwangi yaitu adanya garis putih melintang pada bagian otot-abdomen seperti kapas atau warna merah pada bagian badan udang sampai di ujung ekor (Gambar 2B). Gejala tersebut sama dengan yang diamati oleh Senapin et al., 2007. Kasus infeksi IMNV pada budidaya udang $L$. vannamei yang teridentifikasi pertama kali pada tahun 2004 merupakan kasus infeksi yang cukup merugikan walaupun efeknya tidak seburuk pada kasus infeksi WSSV. IMNV ini bersifat sangat lemah dan dapat terus berada dalam tubuh udang selama dalam pertumbuhannya, walaupun infeksi yang diakibatkan oleh IMNV secara kumulatif dapat mencapai 70\% kematian (Nunes et al. dalam Poulos et al., 2006; Poulos \& Lightner, 2006). Hasil pengamatan menunjukkan bahwa kombinasi infeksi (TSV dan IMNV) bisa menyebabkan terjadinya kematian massal seperti kasus yang dialami di Banyuwangi. Kematian yang disebabkan oleh multi infeksi ini mengakibatkan kematian yang sangat parah sehingga merugikan petambak. Kasus multi-infeksi Monodon baculovirus (MBV dan WSSV) pernah juga terjadi pada udang monodon di Filipina (Natividad et al., 2006). Selain itu, kasus multi infeksi lain yang lebih parah, dalam satu tubuh udang monodon ditemukan adanya tiga patogen MBV, HPV, dan WSSV secara bersamaan (Manivannan et al., 2002). Kasus multi infeksi (tri-infeksi) terjadi juga di Indonesia pada tahun 2009 pada budidaya udang organik (P. monodon) tepatnya terjadi di Sidoarjo, Indonesia; udang-udang tersebut

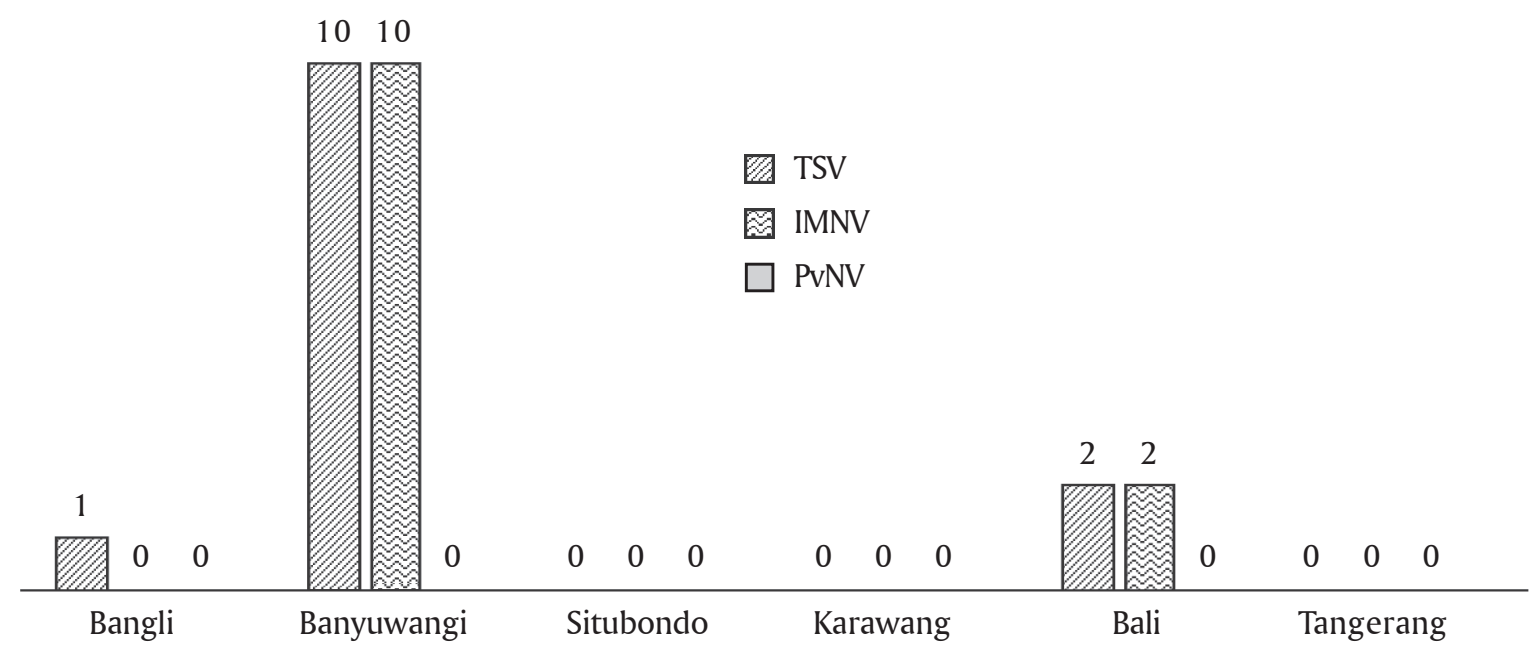

Gambar 1. Sebaran infeksi RNA virus TSV, IMNV, dan PvNV di beberapa sentra budidaya L. vannamei Figure 1. Infection of RNA virus, TSV, IMNV, and PvNV distribution in several center of L. vannamei pond cultures 

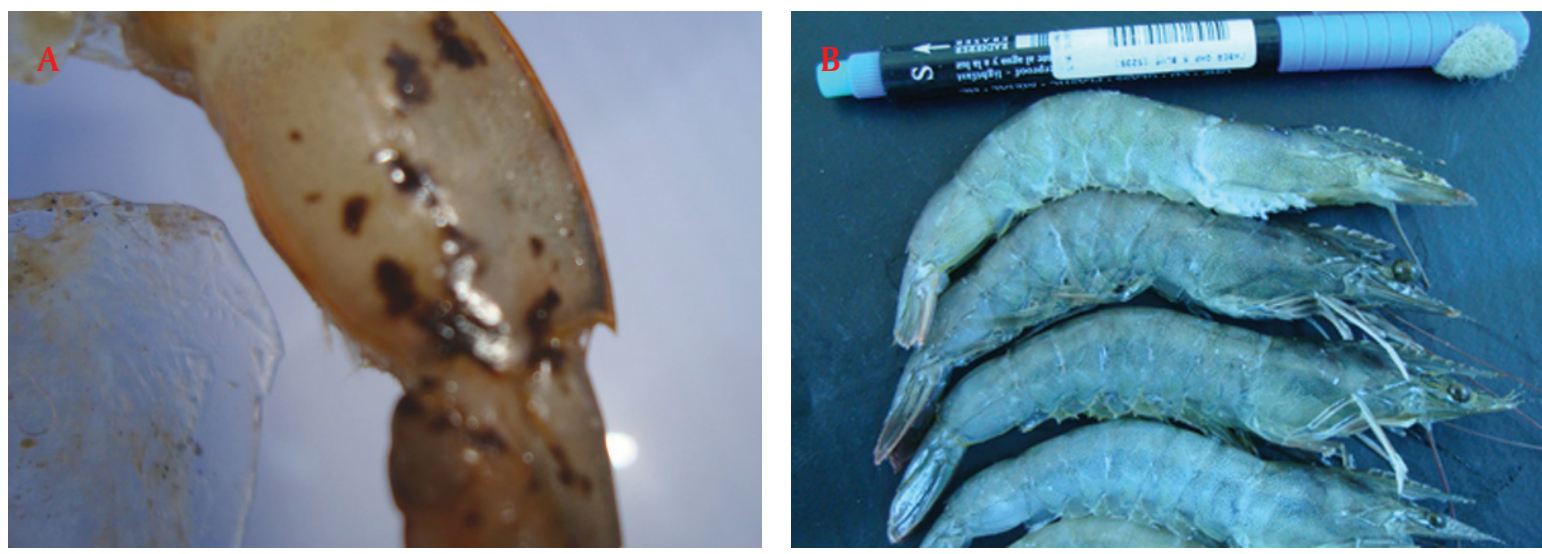

Gambar 2. Gejala infeksi TSV: melanisasi atau kromatofor dan nekrosis pada permukaan kulit (A) dan gejala IMNV: garis putih melintang pada bagian abdomen dan ekor yang merah (B)

Figure 2. TSV symptome: melanization or chromathophore and necrosis on body surface of shrimp (A) and IMNV infected shrimp: white striated muscle in the abdominal and red coloration in tail (B)

mati secara massal, setelah diamati dan diidentifikasi ternyata kematian massal tersebut diakibatkan oleh serangan multi-infeksi DNA virus WSSV, IHHNV, dan MBV secara bersamaan di dalam tubuh udang (in press Koesharyani, 2009).

Hasil amplifikasi PCR dengan spesifik primer (TSV, IMNV, dan $P v \mathrm{NV}$ ) yang diekspresikan pada agarose gel, menunjukkan bahwa untuk TSV dan IMNV masing-masing mempunyai target bobot molekul 230 bp dan 600 bp. Serta PvNV dengan target bobot molekul 339 bp. Untuk mendiagnosa $P v N V$, pada penelitian ini tidak menggunakan positif kontrol atau plasmid $P v$ NV karena sulit untuk mendapatkannya. Diharapkan bila dalam pengujian ini ternyata ditemukan target pita pada 339 bp positif tanda adanya $P v N V$, selanjutnya sampel ini akan dijadikan positif kontrol dan akan dianalisis sekuen untuk mengetahui dari mana sumbernya. Hasil analisis deteksi RNA virus (TSV, IMNV, dan $P v N V)$ menggunakan RT-PCR ini dapat dilihat pada Gambar 3.

Dengan masih adanya kasus infeksi TSV dan IMNV pada sentra budidaya udang, maka perlu lebih diwaspadai, yaitu dengan sistem pengawasan yang baik terutama dalam menentukan status kesehatan udang yang harus dimulai dari kualitas induk yang bebas dari infeksi virus maupun patogen lainnya. Di samping itu, pengawasan penyakit selama proses pembenihan di hatcheri dan sebelum penebaran, serta selama pembesaran di tambak perlu ditindaklanjuti. Oleh karena itu, monitoring serta metode diagnosis yang baik dan tepat sangat diperlukan dalam menentukan kesehatan udang selama proses budidaya.

Hasil pengamatan terhadap kasus infeksi $P v N V$ belum ditemukan pada lokasi budidaya L. vannamei di Indonesia. Namun demikian tidak tertutup kemungkinan kasus infeksi PvNV tersebut akan terjadi di Indo- nesia bila ketentuan dan regulasi tentang impor induk udang L. vannamei tidak diatur dengan baik. PvNV merupakan virus dari Famili Nodaviridae, genus Alphanodavirus dan sangat dekat kekerabatannya dengan Macrobrachium rosenbergii nodavirus (MrNV). Di Belize dilaporkan juga bahwa $P v N V$ mempunyai beberapa vectors, yang keberadaannya dapat dideteksi dengan RT-PCR dan virus ini dapat ditemukan pada kotoran seabird (burung laut) dan beberapa jenis organisme aquatik yang didapat di sekitar tambak udang. $P v \mathrm{NV}$ terdeteksi pula pada mosquito-fish, kotoran seabird, kijing (barnacles), dan zooplankton. Hal ini menunjukkan bahwa $P v N V$ dapat menyebar melalui beberapa organisme tersebut sebagai carrier (Tang et al., 2011).

Status kesehatan udang harus terus-menerus dilakukan pemantauannya melalui deteksi dini. Dengan adanya perubahan iklim yang terjadi sangat fluktuatif saat ini, maka tidak tertutup kemungkinan terjadinya mutasi virus yang mengakibatkan perubahan sifat virus tersebut menjadi lebih membahayakan.

\section{KESIMPULAN}

Hasil pemantauan terhadap sebaran infeksi virus, TSV ditemukan di sentra budidaya udang di Bangil (1/7), Banyuwangi (10/10), dan Bali (2/18) dan infeksi IMNV hanya terdapat di Banyuwangi (10/10) dan Bali (2/18). Kasus multi infeksi IMNV dan TSV terjadi di sentra budidaya Banyuwangi. Infeksi $P v N V$ penyakit virus udang yang relatif baru belum ditemukan di Indonesia.

\section{SARAN}

Pemantauan secara rutin pada kegiatan budidaya udang perlu dilakukan terhadap infeksi penyakit, baik yang disebabkan oleh virus atau patogen lainnya. 

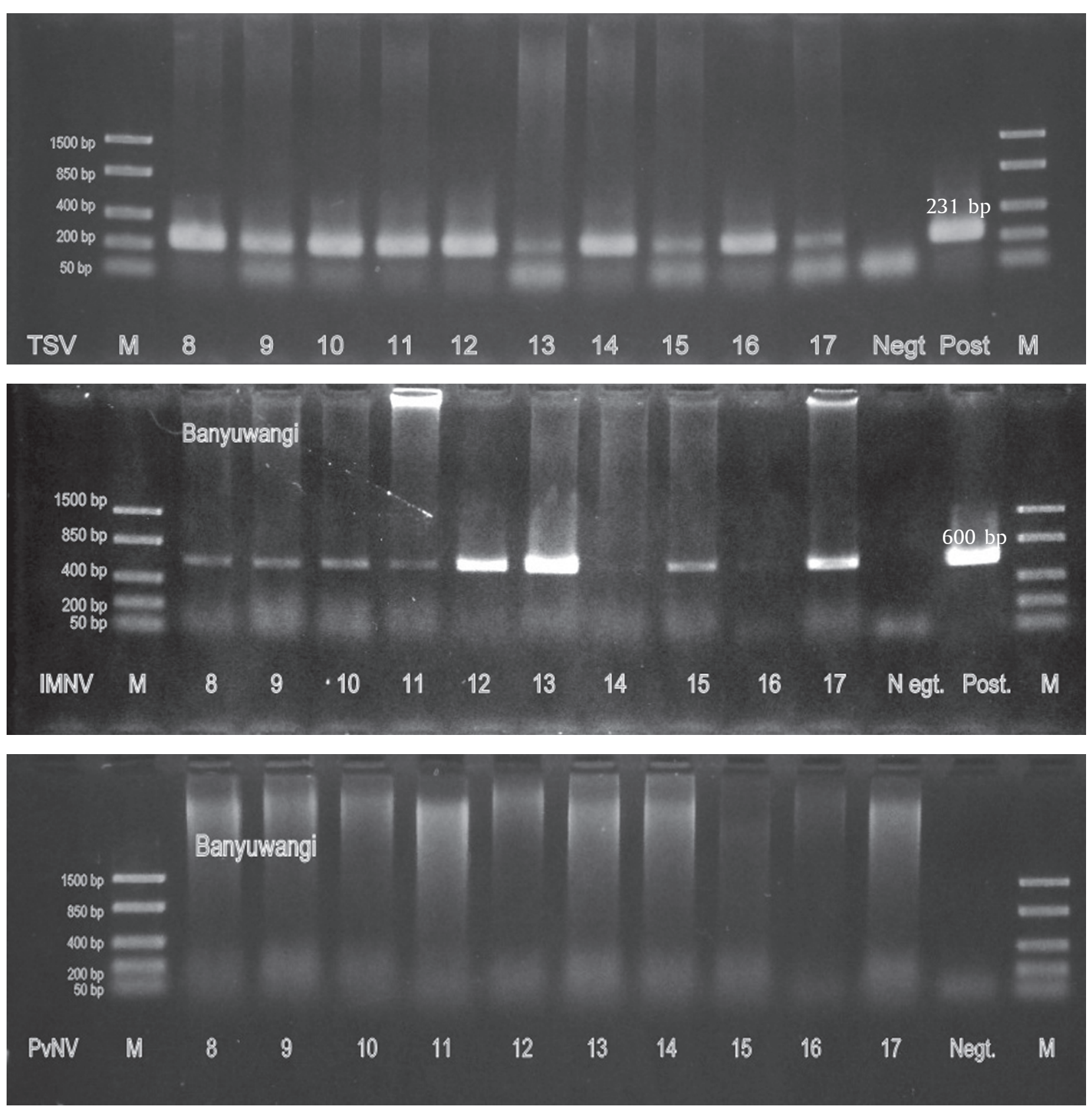

Gambar 3. Hasil deteksi (TSV dengan bobot molekul 230 bp, IMNV 600 bp, dan PvNV 339 bp) dengan metode RT-PCR pada sampel udang $L$. vannamei yang berasal dari beberapa lokasi budidaya

Figure 3. Detection result of TSV 230 bp, IMNV 600 bp, and PvNV 339 bp by using RT- PCR method of L. vannamei shrimp samples from different pond culture

Kewaspadaan dan regulasi terhadap kegiatan impor udang harus lebih diperketat, agar tidak terjadi introduksi penyakit baru.

\section{DAFTAR ACUAN}

Andrade, T.P.D., Srisuvant, T., Tang, K.F.., \& Lightner, D.V. (2007). Real-time reverse transcription polymerase chain reaction assay using TaqMan probe for detection and quantification of infectious myonecrosis virus (IMNV). Aquaculture, 264, 9-15. Aranguren, L.F., Salazar, M., Tang, K., Caraballo, X., \&
Lightner, D.V. (2013). Characterization of a new strain of Taura syndrome virus (TSV) from Colombian shrimp farms and the implication in the selection of TSV resistant lines. Journal of Invertebrate Pathology, 112, 68-73.

Bonami, Jean-R., Hasson, K.W., Mari, J., Poulos, B.T., \& Lightner, D.V. (1997). Taura syndrome of marine penaeid shrimp: characterization of the viral agent. Journal of General Virology, 78, 313-319.

Kiatpathomchai, W., Jareonram, W., Jitrapakdee, S., \& Flegel, T.W. (2007). Rapid and sensitive detec- 
tion of Taura syndrome virus by reverse transcription loop-mediated isothermal amplification. Journal of Virological Methods, 146, 125-128.

Koesharyani, I., Supriyadi, H., Mufidah, T., \& Gardenia, L. (2009). Aplikasi dan validasi metode diagnostik DNA virus udang IHHNV, MBV dan WSSV secara paralel dan multiplek. Laporan Teknis APBN 2009. $18 \mathrm{hlm}$.

Lightner, D.V., Redman, R.M., Hasson, K.W., \& Pantoja, C.R. (1995). Taura Syndrome in Penaeus vannamei (Crustacea: Decapoda): gross sign, histopathology and ultrastructure. Dis. Aquat. Org., 21, 53-39.

Manivannan, S., Otta, S.K., Karusanagar, I., \& Karusanagar, I. (2002). Multiple viral infection in Penaeus monodon shrimp postlarvae in an Indian hatchery. Dis. Aquat. Org., 48 233-236.

Mufidah, T., Koesharyani, I., Supriyadi, H., \& Novita, H. (2009). Infeksi Infectious Myonecrosis Virus (IMNV) pada budidaya udang vaname (Penaeus vannamei) di Jawa Timur. Prosiding Inovasi Teknologi Akuakultur. hlm. 945-949.

Natividad, K.D.L., Migo, M.V.P., Albaladejo, J.D., Magbanua, J.P.V., Nomura, N., \& Matsumura, M. (2006). Simultaneous PCR detection of two shrimp virus (WSSV and MBV) in post larvae of Penaeus monodon in the Philippines. Aquaculture, 257, 142149.

Nunan, L.M., Poulos, B.T., \& Lightner, D.V. (1998). Reverse transcription polymerase chain reaction (RT-PCR) used for the detection of taura syndrome virus (TSV) in experimentally infected shrimp. Diseases of Aquatic Organisms, 34, 87-91.

Novita, H., Mufidah, T., \& Koesharyani, I. (2009). Perbandingan penggunaan berbagai preservasi RNA jaringan dengan RNA Later, alkohol dan alkohol-glyserol untuk deteksi IMNV dengan PCR. J. Ris. Akuakultur, 4(3), 377-383.

OIE. (2015). Report of the meeting of the OIE Aquatic Animal Health Standards Commission. 216 pp.
OIE. (2009). Manual of diagnostic tests for aquatic animal.

Poulos, B.T., \& Lightner, D.V. (2006). Detection infection with infectious myonecrosis virus (IMNV) of penaeid shrimp by Reverse-Transcriptase Polymerase Chain Reaction (RT-PCR). Dis. Aquat. Org., 73, 69-72.

Poulos, B.T., Kibler, R., Bradley-Dunlop, D., Mohney, L.L., \& Lightener, D.V. (1999). Production and use of antybodies for detection of Taura syndrome virus in penaid shrimp. Dis. Aquat. Org., 37, 99106.

Senapin, S., Phewsaiya, K., Briggs, M., \& Flegel, T.W. (2007). Outbreaks of infectious myonecrosis virus (IMNV) in Indonesia confirmed by genome sequencing and use of an alternative RT-PCR detection method. Aquaculture, 266, 32-38.

Senapin, S., Phiwsaiya, K., Gangnonngiw, W., \& Flegel, T.W. (2011). False rumours of disease outbreaks caused by infectious myonecrosis virus (IMNV) in the whiteleg shrimp in Asia. Journal of Negative Results in BioMedicine, 10, 10; http://www.jnrbm. com/content/10/1/10

Tang, K.F.J., Pantoja, C.R., Redman, R.M., \& Lightner, D.V. (2007). Development of in situ hybridization and RT-PCR assay for the detection of a nodavirus $(P v N V)$ that causes muscle necrosis in Penaeus vannamei. Dis. Aquat. Org., 75, 183-190.

Tang, K.F.J., Pantoja, C.R., Redman, R.M., Navarro, S.A., \& Lightner, D.V. (2011). Ultrastructural and sequence characterization of Penaeus vannamei nodavirus (PvNV) from Belize. Dis. Aquat. Org., 94, 179-187.

Suebsing, R., Prombun, P., \& Kiatpathomchai, W. (2013). Reverse transcription loop-mediated isothermal amplification (RT-LAMP) combined with colorimetric goldnanoparticle (AuNP) probe assay for visual detection of Penaeus vannamei nodavirus $(P v N V)$. The Society for Applied Microbiology, ISSN 0266-8254, p. 1-8. 